\title{
Effect of temperature on volume change behaviour of statically compacted kaolin clay
}

\author{
Ogechi lleme $^{1, a}$, Gabriela Medero ${ }^{1}$ and Peter Woodward ${ }^{1}$ \\ ${ }^{1}$ School of Energy, Geoscience, Infrastructure and Society, Heriot-Watt University, United Kingdom.
}

\begin{abstract}
Several soils are subjected to high temperature due to the environment where they are located or activities around them. For instance, upper layer of soils in tropical regions, soils around geothermal structures, clay barriers around nuclear waste repository systems. Numerous studies have pointed out that high temperature affects the hydromechanical properties of soils. Notwithstanding already existing studies, the influence of temperature on soils is still a challenge, as most of these studies are soil specific and cannot be inferred as the behaviour of all soils. This paper presents an experimental study on the influence of temperature on the volume change behaviour of statically compacted kaolin clay. Compacted samples were tested at varying temperatures using a suction controlled oedometer cell. The influence of temperature on the magnitude of volumetric strain occurring during mechanical and thermal loading was investigated. The study showed that an increase in temperature increased the magnitude of volumetric strain of the soil on loading. Additionally, the results presented in the light of LC curve showed that an increase in temperature resulted in the contraction and a change in the position of the LC curve.
\end{abstract}

\section{Introduction}

The number of geo-mechanical problems involving thermal effects on unsaturated soils are on the increase due to technological advancement. Compacted and natural unsaturated soils are increasingly being used in applications where they are subjected to high temperature, which together with imposed load or/and wetting condition affect their behaviour and mechanical properties. For instance, the use of compacted clay blocks as liners for waste disposal and as barriers in nuclear waste repository [1].

Significant amount of work has been done on the influence of temperature on soils. For saturated soils, the major temperature effect reported by different authors [2 - 9] are; heating induces expansion under high OCR at low net stress and contraction under low OCR. Thermal expansion observed on heating at low vertical net stress is attributed to expansion of soil constituents; water and solid whereas the thermal contraction on heating at high vertical net stress is ascribed to weakening of contacts between aggregates [10].

For unsaturated soils, some of the findings are contradictory. As regards unsaturated expansive soils, their thermal behaviours appear to be somewhat dependent on soil type, suction value and initial density. For a thermal volume change obtained from nonisothermal path at constant suction and vertical stress, $[11,12]$ reported an increase in volumetric strain (expansion) of high density Boom clay with temperature increase coupled with strain accumulation. However, the magnitude of volumetric strain observed on heating decreased with increase in suction. On the contrary, [1] and [13] observed expansion of MX80 and GMZ01 bentonites respectively on heating at high suction values, and then contraction at low suction values. [13] Also reported that the effect of temperature on Boom clay is dependent on OCR value. Thermal contraction increases with decreasing OCR and the temperature at which the transition between contraction and expansion occurs decreases with OCR. Cooling was associated with an irreversible volumetric strain which reduced on subsequent cycles [11]. [13] Noted that cooling process is considered as an elastic process because it involves contraction of the constituent elements, whereas thermal contraction is considered as a plastic process. Another explanation of the phenomena surrounding the thermal behaviour of soils is given by [11]. He explained that thermally induced irreversible behaviour can be linked to structural rearrangement of particles at the macrostructural level as a consequence of thermal expansion at the microstructure.

In the case of loading paths at constant suction and temperature, [1,11, 14, and 15] reported a decrease in yield stress and higher compressibility with temperature increase and as a result, a reduction in the size of the elastic domain. However, [12] observed an increase in yield stress with temperature. But it is worth noting that the samples used by [12] were first subjected to cycles of wetting and drying before being subjected to isothermal loading and unloading. It is then likely that the observed behaviour by [12] was influenced by the initial stress

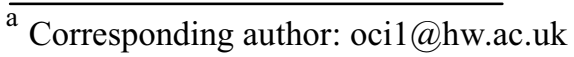


path. $[1,12]$ observed that the compressibility parameters are insensitive to temperature. However, [11, 14] observed from their studies that the post-yield/plastic compressibility parameters are temperature sensitive to temperature, but the pre-yield/elastic compressibility parameters are insensitive to temperature. [11] observed an increase in the compressibility parameter with temperature, whereas [14] observed a slight decrease with temperature. It is worth noting that the findings of [11] and [14] were on different soils with different initial conditions and this may have played a role in the difference. In fact, studies by $[15,16]$ showed that the influence of temperature on compressibility appears to be dependent on some factors such as over-consolidation ratio, plasticity, expansibility and compaction water content or suction.

For unsaturated, non-expansive soils, some of the reported behaviours are similar to those observed on expansive soils, with the direction of volume change usually contraction. However, [17] reported expansion of silty clay when heated at low suction and net applied stress. Under non-isothermal path, [17] and [18] observed an increase in contraction of sandy silt and silt respectively, with increasing temperature, although [17] observed this at high initial suction and net stress. Most findings on the effect of temperature on compressibility parameters and yield pressure are unanimous for nonexpansive soils. The compressibility parameters were reported to be unaffected by temperature $[18,17]$. The yield pressure reduces with increasing temperature, thereby shrinking the yield surface; a condition known as thermal softening [17, 18, 19, 20, 21, 22, and 23]. Also, the increase in temperature induces decrease in resilient modulus [21].

From literature, temperature effect on mechanical behaviours appears to be dependent on soil type and other factors. In this study, the influence of temperature on the volume change behaviour of compacted kaolin clay was investigated. Kaolin clay is a benchmark soil used for research, as a result, understanding its thermo-hydromechanical behaviour is essential. Most of the studies on the thermo-hydro-mechanical behaviours of kaolin clay were carried out on reconstituted samples with moisture contents on the wet side of optimum [22, 23]. Evidence has shown that a sample compacted at a water content wet of optimum is significantly different from that compacted to a dry of optimum water content in terms of their structure and mechanical behaviour [24]. Consequently, temperature effect on the behaviour of kaolin clay samples prepared at the dry side of optimum is still needed to have a full understanding of the thermal behaviour of the soil. The effect of temperature on volume change and compressibility was studied using a suction and temperature controlled oedometer cell. Two testing paths were followed;

a) Loading at constant suction and temperature.

b) Heating and cooling at constant suction and vertical net stress.

\section{Material, sample preparation and method}

\subsection{Material}

The soil used for the study is industrially manufactured kaolin clay. The soil has a liquid limit, a plastic limit and plasticity index of $59.1 \%, 33 \%, 26 \%$ respectively and a specific gravity of 2.65 . The hygroscopic water content in equilibrium with the laboratory atmosphere is $0.23 \%$. The kaolin clay constitutes $58 \%$ silt fraction and $42 \%$ clay fraction. X-ray diffraction indicated a mineralogical composition of $82 \%$ Kaolinite, 15\% Quartz and 3\% Illite and Mica [23]. Results from standard proctor compaction test indicated a maximum dry density of $1.41 \mathrm{Mg} / \mathrm{m} 3$ and an optimum water content of $27 \%$.

\subsection{Sample preparation}

Statically compacted samples; B1 and B2 were used for the study as shown in Table 1. B2 could be described as aggregated samples made of saturated macropeds [25] with large void spaces in-between the macropeds. Preliminary double oedometer tests on B2 showed high magnitude of collapse on wetting and loading. The intention in B2 was to investigate if temperature increase will have the same effect as observed on wetting or loading. Both samples were prepared at different degrees of saturation, but the same void ratio. It is worth mentioning that both B1 and B2 were considered as different samples and that results from both samples were not compared.

The samples were prepared by mixing the required mass of oven dried soil thoroughly with the required quantity of de-aired water to achieve the specified water content. Thereafter, the material for B1 was passed through a sieve of $1.18 \mathrm{~mm}$ aperture while that of B2 was passed through a sieve of $2.8 \mathrm{~mm}$ aperture. This was still considered adequate relative to the height of the oedometer ring $(20 \mathrm{~mm})$. The materials for B1 and B2 were then transferred into plastic bags, sealed and left for $24 \mathrm{hrs}$ for moisture equilibration. Afterwards, the samples were statically compacted into oedometer rings $(50 \mathrm{~mm}$ diameter, $20 \mathrm{~mm}$ high) using an oedometer frame. Static compaction was adopted to ensure uniform density in the samples [26, 27]. Different compaction pressures were used to compact the samples to achieve the desired void ratio. After compaction, the samples were carefully transferred into the suction controlled oedometer cell for testing.

\subsection{Method}

\subsubsection{Suction controlled oedometer cell}

The suction controlled oedometer cell used for testing was designed by [23]. General scheme of the oedometer cell is shown in Figure 1. The cell made of stainless steel has two main parts; cell body with an internal chamber for the sample and the cell cover. The cell body has an external and internal diameter of $101 \mathrm{~mm}$ and $51 \mathrm{~mm}$ respectively, with a height of $70 \mathrm{~mm}$. Inside the internal chamber is the ring that retains the sample. Suction is 
imposed on samples using axis translation technique. A porous stone of about $5 \mathrm{~mm}$ thick with a diameter slightly less than the diameter of the ring sits on top of the sample. Pore air pressure is applied to the sample through this porous stone. At the base of the cell is a high air entry ceramic disc (with air entry value of $1500 \mathrm{kPa}$ ), which acts as an interface between the sample and a water reservoir for imposing pore water pressure. Two recesses fitted with valves are located at the base of the cell; one for water inlet into the reservoir and the other for water outlet and flushing the cell.

The cell cover is fitted with a $1 \mathrm{~mm}$ flat diaphragm attached without gap to the loading cap; the loading cap transmits load evenly on the sample by means of air pressure acting on the diaphragm. The diaphragm acts as an interface between the diaphragm chamber and the internal chamber of the cell and can withstand temperature up to $150^{\circ} \mathrm{C}$ [23]. A hollow stainless piston of $13 \mathrm{~mm}$ external diameter passes through the centre of the loading cap, diaphragm as well as cell cover and is soldered to the loading cap at the lower end. The upper end of the piston is fitted with a valve through which connection is made to the air pressure system (for pore air pressure). The flat edge of the valve then provides a base for the anvil of LVDT used for monitoring the displacement in the sample. Two upper recesses are located on the cell cover, one of which is used for connection to the air pressure system, for applying diaphragm pressure. Temperature was imposed on the samples using a temperature chamber capable of maintaining temperature ranging between $0^{\circ} \mathrm{C}$ and $50^{\circ} \mathrm{C}$. Prior to testing, the cell was calibrated to determine the actual pressure transmitted to the sample for each value of diaphragm pressure under a given value of matric suction. This was done using a calibrated proven ring with a load factor of $1.21 \mathrm{~N}$. The time required for the sample to reach thermal equilibrium was assessed by burying a calibrated thermocouple at the centre of a compacted sample in the cell and monitoring the time required for the sample to attain the same temperature as the temperature chamber. Details and results of the calibrations can be found in [23].

Table 1. Initial conditions

\begin{tabular}{|c|c|c|c|c|}
\hline Sample & $\mathbf{S r}_{\mathbf{i}}(\mathbf{\%})$ & $\mathbf{e}_{\mathbf{i}}$ & $\begin{array}{c}\text { Initial } \\
\text { suction } \\
(\mathbf{k P a})\end{array}$ & $\begin{array}{c}\text { Compaction } \\
\text { pressure } \\
(\mathbf{k P a})\end{array}$ \\
\hline B1 & 30.0 & 1.49 & 286 & 203 \\
\hline B2 & 58.6 & 1.47 & 109 & 113 \\
\hline
\end{tabular}

\subsubsection{Testing procedure}

\section{Non-isothermal path at constant suction and stress}

The aim was to observe the influence of thermal cycles on the volume change of compacted samples under a constant matric suction and vertical net stress.
Temperature was varied between $25^{\circ} \mathrm{C}-50^{\circ} \mathrm{C}$. A vertical net stress of $55 \mathrm{kPa}$ was maintained in all the tests and two values of suction $30 \mathrm{kPa}$ and $100 \mathrm{kPa}$ were considered. The test was carried out on sample B1 and B2. In total four tests were carried out, namely $\mathrm{NI}_{1}$, $\mathrm{NI}_{2}, \mathrm{NI} 2_{1}$, and $\mathrm{NI}_{2}$. Both $\mathrm{NI} 1_{1}$ and $\mathrm{NI} 1_{2}$ have the same initial conditions (as in B1) and were tested at different suction values $30 \mathrm{kPa}$ and $100 \mathrm{kPa}$ respectively indicated by the subscript. Similarly, NI $2_{1}$, and NI $2_{2}$ have the same initial conditions (as in B2) and were tested at suction of $30 \mathrm{kPa}$ and $100 \mathrm{kPa}$ respectively. Prior to testing compacted sample was placed on top of the saturated ceramic disc and the cell assembled quickly to prevent the sample from taking up water from the stone. Suction was reduced to $30 \mathrm{kPa}$ or $100 \mathrm{kPa}$ from an initial value of $109 \mathrm{kPa}$ and $286 \mathrm{kPa}$ for $\mathrm{B} 2$ and $\mathrm{B} 1$ respectively. The volume change in the sample was monitored and recorded. This was maintained for 14 days for suction equalisation. The 14 days equalisation time was adopted from the study of [23]. He monitored water volume movement in compacted kaolin clay on reducing suction to $0 \mathrm{kPa}$. He observed that the rate fell to less than 0.015/day after 14 days. After suction equalisation, vertical net stress was increased to $55 \mathrm{kPa}$ and maintained for 24 hours. Then thermal loading was imposed following three temperature steps; $25^{\circ} \mathrm{C}, 35^{\circ} \mathrm{C}$ and $50^{\circ} \mathrm{C}$. For each step, the temperature was increased in several sub steps at a rate of $2^{\circ} \mathrm{C}$ per hour. Resulting in 5 hours from $25^{\circ} \mathrm{C}$ to $35^{\circ} \mathrm{C}$ and 7.5 hours from $35^{\circ} \mathrm{C}$ to $50^{\circ} \mathrm{C}$. [19] Explained that adopting small temperature steps will reduce the build-up of excess pore water pressure that may result in an over-consolidated behaviour of the sample. The stress path is shown in Figure 2 as Nonisothermal path. Continuity of pore water pressure was always ensured during testing by flushing the water lines periodically.

\section{Loading path at constant suction and temperature}

The test was carried out on only samples B1. Two constant temperatures $\left(25^{\circ} \mathrm{C}\right.$ and $\left.50^{\circ} \mathrm{C}\right)$ and suction values $(30 \mathrm{kPa}$ and $210 \mathrm{kPa}$ ) were considered during testing. The tests were named according to the suction and temperature values. L11 and L12 for suction $30 \mathrm{kPa}$ (first numeric value) and temperature $25^{\circ} \mathrm{C}$ and $50^{\circ} \mathrm{C}$ respectively (second numeric value). L21 and L22 for suction $100 \mathrm{kPa}$ and $25^{\circ} \mathrm{C}$ and $50^{\circ} \mathrm{C}$ respectively.

Following compaction, the sample was placed on the saturated stone and the cell assembled quickly. Then the sample was brought to a suction value of $30 \mathrm{kPa}$ or $210 \mathrm{kPa}$ and then subjected to the desired temperature $\left(25^{\circ} \mathrm{C}\right.$ or $\left.50^{\circ} \mathrm{C}\right)$. A period of 14 days was allowed altogether for thermal and suction equalisation. Displacement of the sample due to suction and temperature changes were measured by the LVDT. Vertical net stresses were applied incrementally from $5 \mathrm{kPa}$ to $400 \mathrm{kPa}$ with five loading steps while maintaining the suction and temperature constant. The stress path is shown in Figure 2 as loading path. It was assumed that the number of loading steps used was enough to prevent significant pore pressure re-distribution. Increase in 
vertical net stress has been reported to cause redistribution of pore water pressures [17], implying that adequate time should be allowed for re-equalization of suction. There was initial concern about allowing 14days for suction re-equalisation for each step of vertical net stress due to time limit. Since the parameter monitored during testing was volume change, deformation of the sample on application of a vertical net stress of $100 \mathrm{kPa}$ at $50^{\circ} \mathrm{C}$ was monitored for 24 hours. It was observed that the deformation $\Delta \mathrm{H}$ fell to less than $0.004 \mathrm{~mm}$ per hour after about 17 hours. Consequently, 24 hours of rest was adopted in all the tests, after each step of vertical net stress.

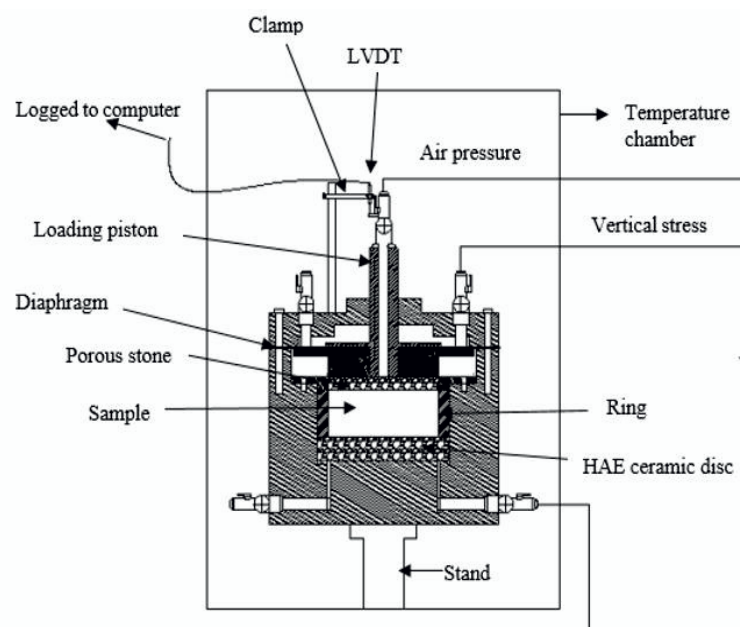

Figure 1. General scheme of suction controlled oedometer

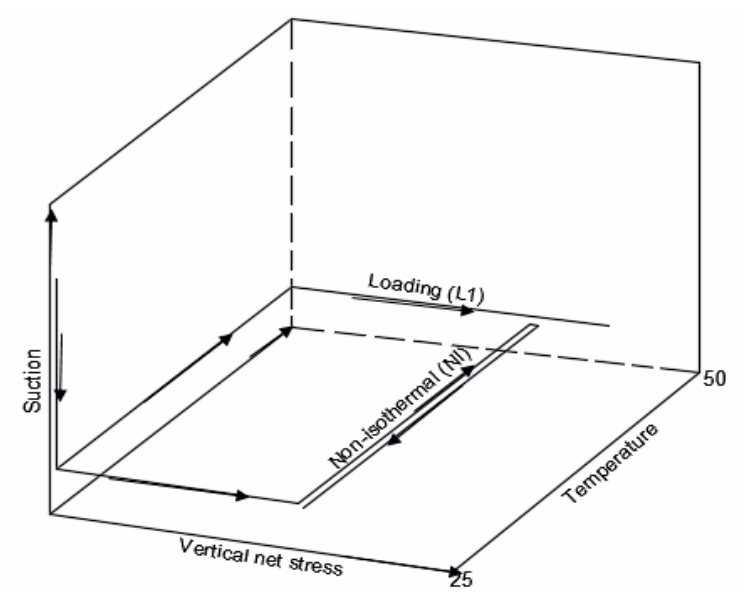

Figure 2. Stress path used during testing

\section{RESULTS AND DISCUSSIONS}

\subsection{Non-isothermal tests}

Non-isothermal tests were carried out to ascertain the volumetric behaviour in response to temperature cycles. Figure 3 shows the volumetric strain from $\mathrm{NI}_{1}$ on a complete temperature cycle. From the Figure, it is evident that heating resulted in contraction of the sample, though small volumetric strain was observed (about $7 \%$ increase by heating from $25^{\circ} \mathrm{C}$ to $50^{\circ} \mathrm{C}$ ). However, on cooling, the strain was irrecoverable. Unfortunately, the test at constant suction of $100 \mathrm{kPa}$ was inconclusive due to equipment break down during testing. Hence, the result could not be compared with that at $30 \mathrm{kPa}$.

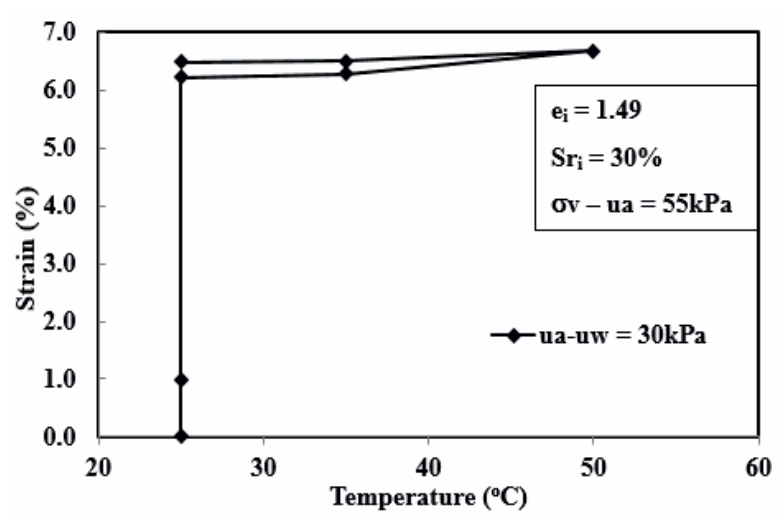

Figure 3. Soil deformation response on heating and cooling $\left(\mathrm{NI} 1_{1}\right)$

Figures $4 \mathrm{a} \& 4 \mathrm{~b}$ show volumetric strain from $\mathrm{NI}_{1}$ and $\mathrm{NI}_{2}$ on heating and cooling respectively. Both samples experienced substantial and irrecoverable volumetric strain (contraction) on heating and cooling. However, it could be clearly seen that $\mathrm{NI} 22_{1}$ tested at a constant suction of $30 \mathrm{kPa}$ experienced higher deformation than $\mathrm{NI}_{2}$ tested at a suction of $100 \mathrm{kPa}$. This could be attributed to a reduction in strength associated with a decrease in suction [36]. Similar behaviour was also reported by [22]; the sample at a constant suction of $0 \mathrm{kPa}$ exhibited higher deformation on heating and cooling than the sample at a suction of $100 \mathrm{kPa}$.

The magnitude of deformation on application of vertical net stress and suction could be seen to be high relative to the deformation on a complete temperature cycle. The highest magnitude of deformation occurred after an increase in vertical net stress (path 2-3) in Figure $4 \mathrm{a} \& 4 \mathrm{~b}$.

\subsection{Loading at constant suction and temperature}

The loading tests L11, L12, L21 and L22 were performed at constant suction $(30 \mathrm{kPa}$ and $210 \mathrm{kPa})$ and temperature $\left(25^{\circ} \mathrm{C}\right.$ and $\left.50^{\circ} \mathrm{C}\right)$. Figure 5 shows the variation of void ratio with vertical net stress for L11 and $\mathrm{L} 12$ at a constant suction of $30 \mathrm{kPa}$. From the figure, it is evident that the soil compressibility increased with temperature increase. For instance, at a vertical net stress of $108 \mathrm{kPa}$, the void ratio for the sample at $25^{\circ} \mathrm{C}$ is 1.146 , while the corresponding void ratio at $50^{\circ} \mathrm{C}$ is 1.0637 . Both NCLs are not parallel and not converging at any point. Since almost exact samples have been used in both tests, it was expected that both lines will converge at some point, probably with further increase in vertical net stress. As loading was done at a constant suction of $30 \mathrm{kPa}$, it is assumed that most of the previously air filled 
voids were became water filled when the matric suction was relaxed from $286 \mathrm{kPa}$ to $30 \mathrm{kPa}$. It is already established that viscosity decreases with temperature. At $50^{\circ} \mathrm{C}$, water held in the voids became less viscous (note that water is not held in-between the silica-alumina layers of kaolin due to strong hydrogen bond). It is possible that the decrease in viscosity aided the consolidation of the samples by quicker expulsion of water from the voids and as a result, a reduction in the volume of voids. This trend in behaviour is not very different from those observed by $[22,23]$ on saturated kaolin samples. The result of this study when compared with results from [23] at the same temperature and void ratio showed a difference in the compressibility parameters and in the position of the yield stress. These differences may be due to difference in fabric induced by compaction water content and compaction pressure. Reconstituted samples were used by [23] with compaction wet of optimum.

Figure 6 shows the stress strain relationship of L11 and L12. The figure shows clearly that compressive strain increased with an increase in temperature from $25^{\circ} \mathrm{C}$ to $50^{\circ} \mathrm{C}$. Additional strain induced in the soil by increase in temperature was maximum at an applied stress of $108 \mathrm{kPa}$. Similar findings (increase in compressive strain with temperature increase) were reported by $[11,22]$. The yield stresses were obtained using Cassagrand method. Yield stresses of $40 \mathrm{kPa}$ and $34 \mathrm{kPa}$ were obtained from L11 and L12 respectively, a $15 \%$ reduction due to increase in temperature from $25^{\circ} \mathrm{C}$ to $50^{\circ} \mathrm{C}$. With the zone before yield stress known as elastic domain and zone after yield stress known as plastic domain, increase in temperature resulted in the reduction of the elastic domain and earlier onset of plastic behaviour. Similar behaviour also known as thermal softening was reported by $[20,22$ and 23]. An increase in the post compressibility parameter $\mathrm{Cc}$ was observed with temperature. This contradicts the findings of $[1,9]$ which states that the slope of the normal compression line is unaffected by temperature, but is in line with the findings of [11] which states that the post-yield compressibility parameters (stiffness parameter and slope of the normal compression line) increase with temperature.

Figure 7 shows compression curves for L21 and L22 (at constant suction of $210 \mathrm{kPa}$ ). No clear difference can be observed between the two curves along the elastic domain. However, along the plastic domain, samples tested at $50^{\circ} \mathrm{C}$ exhibited a slight decrease in void ratio than the sample at $25^{\circ} \mathrm{C}$ at corresponding values of vertical net stresses. This indicates thermal softening at the plastic domain. Similar behaviour was also observed by $[22,23]$ on kaolin clay at a constant suction of $300 \mathrm{kPa}$, but the positions of the yield stresses were significantly different.

At a constant suction of $210 \mathrm{kPa}$, the yield stress was not affected by temperature as shown in Figure 7 . Additionally, the post compressibility parameters were unaffected by temperature increase, in agreement with the findings of $[1,9,12,23]$.

Finally, the effect of temperature on the soil deformation response was presented using LC curve as shown in Figure 8. From the Figure, it could be seen that an increase in temperature resulted in the contraction of the yield curve (only at a suction of $30 \mathrm{kPa}$ ) and a change in the position i.e. a shift to the left. This is similar to the effect of a decrease in compaction stress reported by [28].
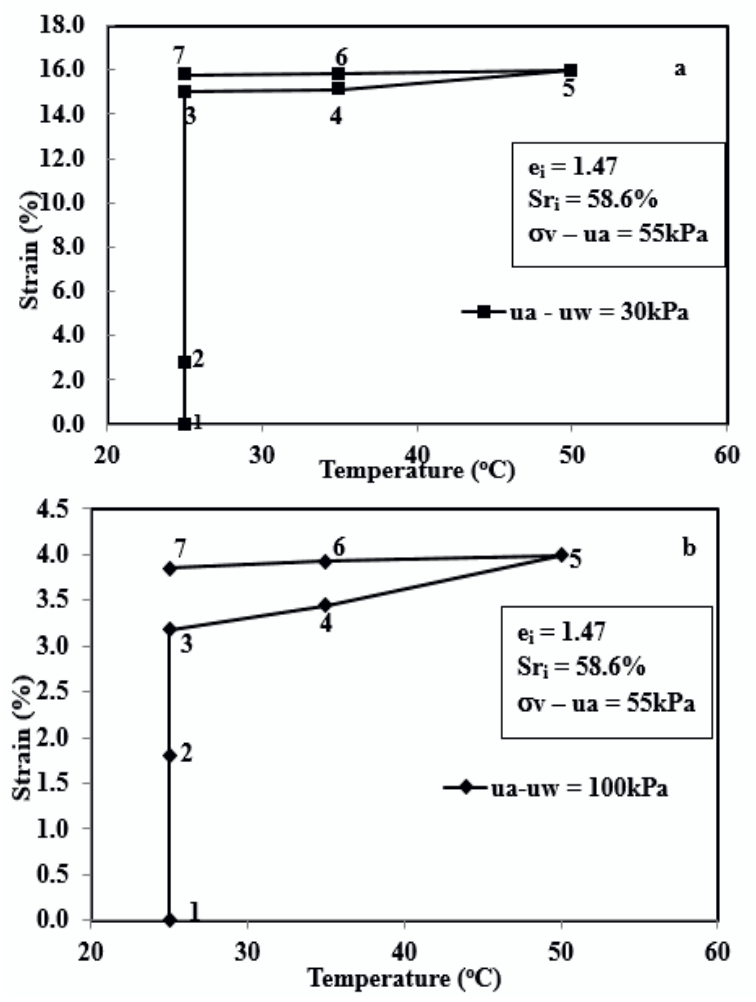

Figure 4. Soil deformation response on heating and cooling a) $\mathrm{NI} 21$ b) $\mathrm{NI} 2_{2}$

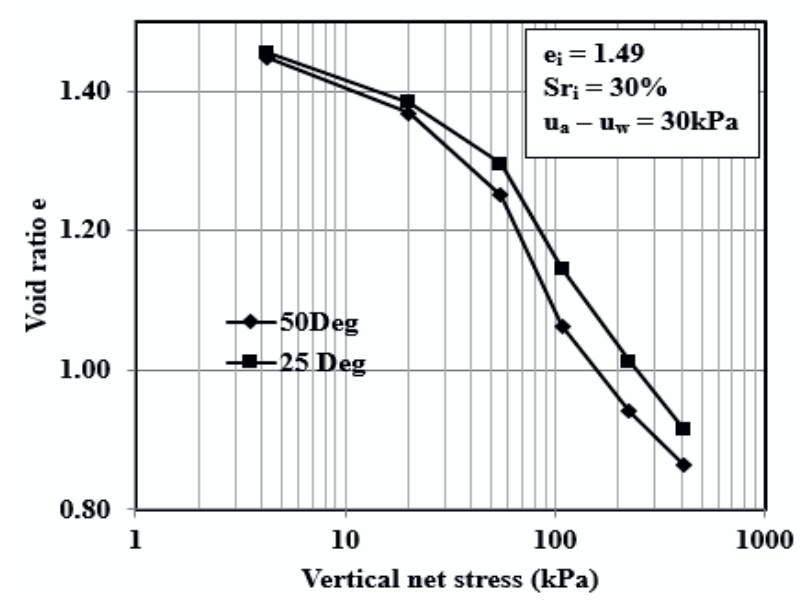

Figure 5. Compression curves for L11 and L12

\section{Conclusions}

Non-isothermal tests and loading tests were performed to investigate the influence of temperature on the volumetric behaviour of statically compacted kaolin clay. Results from non-isothermal test showed that heating induced contraction which was irreversible on cooling. The results also indicated that the volumetric strains associated with change in suction and vertical net stress are usually higher compared to strain induced by 
increase in temperature. Regarding the loading paths, the results showed that compressibility increases with temperature increase, resulting in thermal softening. Yield stress decreased with temperature increase (though only for sample tested at a constant suction of $30 \mathrm{kPa}$ ) resulting in a shift of the $\mathrm{LC}$ curve to the left. The influence of temperature on compacted kaolin at dry of optimum and reconstituted kaolin are different. The magnitude of volume change and the change in position of the yield surface associated with heating are different for both soils.

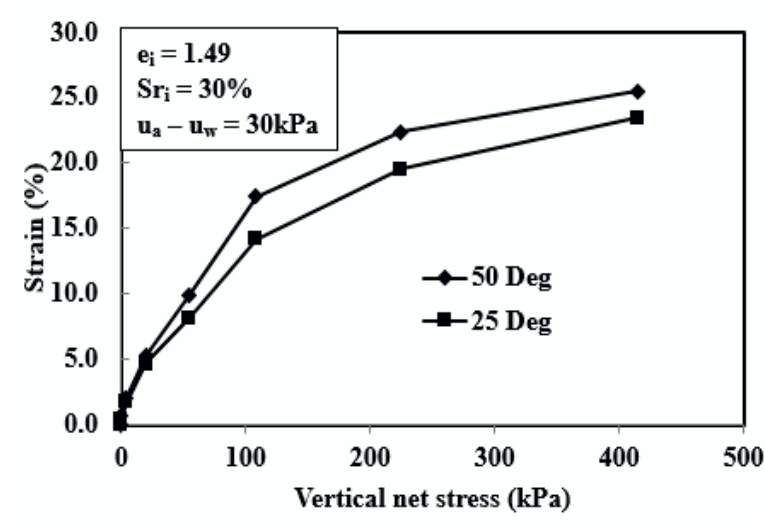

Figure 6. Stress strain relationship of L11 and L12

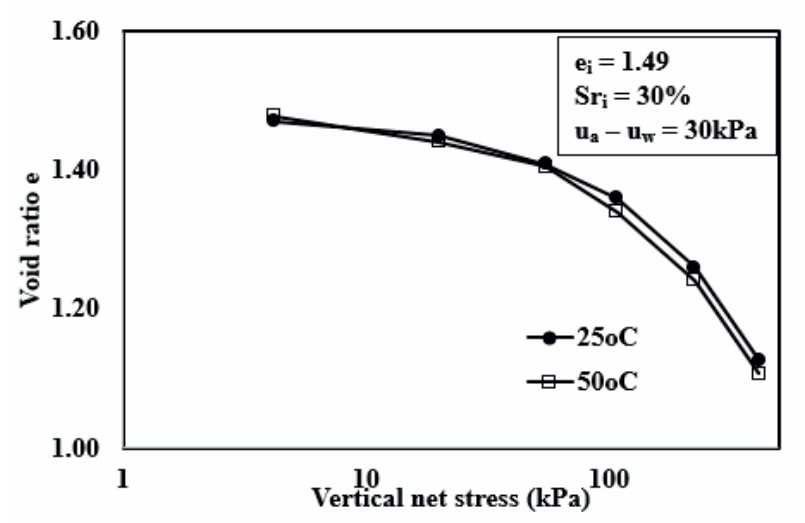

Figure 7. Compression curve for L21 and L22

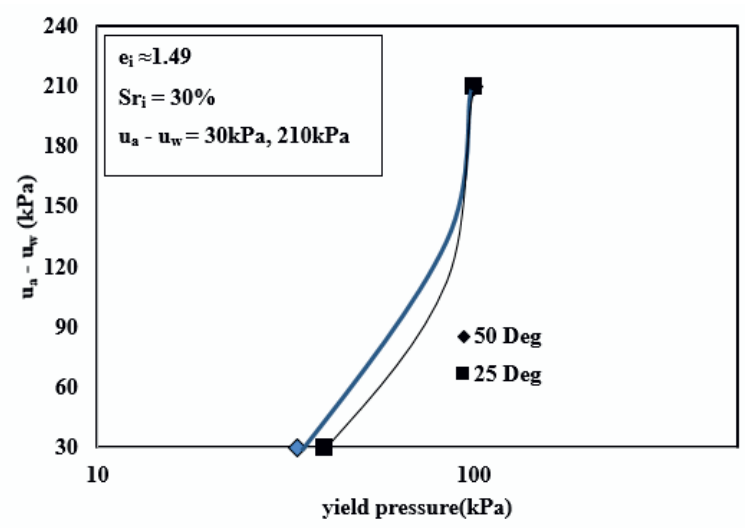

Figure 8. Temperature effect represented on LC curve

\section{References}

1. A. Tang, Y. Cui, B. Nathalie, Geotechnique 58(1), 45-54 (2008)

2. R.G. Campanella, J. R. Mitchell, J. of Soil Mech. Fnd. Div., ASCE. 94 (3), 709-734 (1968)

3. G. Baldi, T. Hueckel, R. Pellegrini, Canadian Geotech. J. 25, 807-825 (1988)

4. T. Hueckel, G. Baldi, J. Geotech. Engng 116(12), 1778-1796 (1990)

5. C. Del Olmo, V. Fioravante, F. Gera, T. Hueckel, J. C. Mayor, R. Pellegrini, Engng. Geol. 41(1-4), 87101 (1996)

6. P. Delage, N. Sultan, Y. J. Cui, Canadian Geotech. J. 37, 343-354 (2000)

7. L. Laloui, Rev. Fr.Ge'nie Civil 5(6), 809-843 (2001).

8. N. Sultan, P. Delage, Y. J. Cui, Engng. Geol. 64 (23), 135-145 (2002)

9. C. Cekerevac, L. Laloui, Int. J. for Numerical and Analytical Methods in Geomechanics. 28(3), 209228 (2004)

10. Y. J. Cui, N. Sultan, P. Delage, Can. Geotech. J. 37(3), 607-620 (2000)

11. E. Romero, A. Gens, A. Lloret, (2003), Geotechnique. 53, 65-81 (2003)

12. E. Romero, M. V. Villar, A. Lloret, Engineering Geol. 81, 255-268 (2005)

13. Y. J. Cui, M. J. Tang, J. of Rock Mech. \& Geol. Engng. 5, 169-178 (2013).

14. M. W. Ye, Y. W. Zhang, Y. G. Chen, Y. J. Cui, Applied Clay Sci. 83-84, 210-216 (2013)

15. A. Lloret, M. V. Villar, Physics and Chemistry of the Earth. 32, 701-715 (2007)

16. M. V. Villar, A. Lloret, Applied Clay Sci. 26(1), 337-350 (2004)

17. A. Uchaipichat, N. Khalili, Geotechnique. 59, 339353 (2009).

18. S. Salager, B. Francois, M. S. El Youssoufi, L. Laloui, C. Saix, Soils and Fnd. 48(4) 453-466 (2008)

19. B. François, S. Salager, M. S. El Youssoufi, D. Ubals Picanyol, L. Laloui, C. Saix, Proceedings, computer application in geotechnical engineering. 1-10 (2007)

20. C. W. W. Ng, C. Zhou, Geotechnique 64(9) 709-720 (2014)

21. A. Di Donna, L. Laloui, Engng. Geol., 190, 65-76 (2015)

22. J. P. W. Folly, PhD Thesis, Cardiff University (2001)

23. A. Haghighi, $\mathrm{PhD}$ thesis, Heriot-Watt University (2011)

24. A. Gens, E. E. Alonso, J. Suriol, A. Lloret, Proc. Ist Int. Conf. on Unsat. Soils, Paris. 83-88 (1995)

25. E. C. Lawton, R. J. Fragaszy, M. D. Hetherington, Journal of Geotech. Engng, 118, 1376-1394 (1992).

26. B. V. Venkatarama, Reddy, K. S. Jagadish, Geotechnique. 43(2), 337-341 (1993)

27. V. Sivakumar, $\mathrm{PhD}$ thesis, University of Sheffield (1993).

28. V. Sivakumar, S. J. Wheeler, Geotechnique, 50(4), 359-368 (2000) 